\title{
Outobiografie of nie: aantekeninge oor die outobiografiese aanwysers in enkele Afrikaanse tekste
}

\begin{abstract}
Abstracl
The autobiographical relationship between the concrete author and a character or narrator in a text has always been a problem in the study of literature. In this article it is illustrated how certain signals in the text may function as autobiographical indicators. These signals must direct the reader towards an autobiographical interpretation of a specific text, because this is often essential for an adequate reading of such a text. The methodological approach of this article is, though, that an autobiographical interpretation of a text should at all times be textually confirmed. Texts included in this study are Somer 11 and Suidpunt-jazz (André Letoit), Jonkmanskas and Die hemel help ons (Koos Prinsloo), Van stiltes en stemme (J.M. Gilfillan), Die droom (Uys Krige), Wynand se oorlog (Ria Jordaan), Sleep vir jou 'n stoel nader (Andre le Roux) and Klaaglied vir Koos (Lettie Viljoen).
\end{abstract}

\section{Inleiding}

Die munt van die term persona ${ }^{1}$ in die literatuurkritiek van die veertigerjare, het uiteindelik 'n naam gegee aan een van die (vele) probleemkinders in die literatuurstudie: die rol van die outobiografiese 'ek' in die literêre teks. Die verskynsel van die (skyn)outobiografiese ek-spreker en sy betrokkenheid by, of aanspreeklikheid tot gebeure in die teks was nog altyd rede vir 'n akademiese dispuut onder kritici, spekulasie onder lesers, én verontwaardiging van konkrete outeurs wat dikwels tot 'verantwoording' geroep word in onderhoude en gesprekke. En nog is die laaste woord nie gespreek nie.

Die term persona word gebruik om die verwantskap tussen die konkrete outeur en die karakters wat hy skep te verklaar (Elliot, 1982:x). Die projeksie van outeur na karakter is nooit 'n eenvoudige verwantskap nie, maar dit word verál ingewikkeld as dit duidelik is dat daar mér as net die formele verhouding van outeur tot sy karakter-van-papier by die situasie betrokke is. Só 'n situasie ontstaan wanneer die karakter in 'n teks dieselfde naam as die outeur het, of as daar opvallende outobiografiese verbande tussen die konkrete outeur en sy karakter is, en hierdie verbandlegging eksplisiet of implisiet deur die leser rekonstrueerbaar is. Dit het tot die konsep van die sogenaamde 'outobiografiese ek' gelei 'n verskynsel wat nog altyd in literatuur voorgekom het, maar in die literatuur van die tagtigerjare 'n prominente verskyning in Afrikaanse tekste begin maak het. Hier word veral gedink aan digters soos onder andere D.J. Opperman (Komas uit 'n bamboesstok), Daniel Hugo (Die boek Daniël) Joan Hambidge (Die somber muse); en prosaiste soos Koos

\footnotetext{
${ }^{1}$ Vir 'n volledige omskrywing en geskiedenis van dié term se ontstaan, kyk Robert Elliot se The literary persona (1982).
} 
Prinsloo, André Letoit, en in 'n meer verskuilde gedaante, Rita Gilfillan. Met die uitsondering van Uys Krige se Die droom word daar in hierdie artikel gekonsentreer op die prosa van die jongste generasie skrywers. Ander werke wat ewe goed betrek sou kon word is onder andere die werk van MER, Miskien nooit van André P. Brink en Die koningin van Skeba van S.J. du Toit.

In 'n ongepubliseerde artikel "Die teruggekeerde Opperman: Die funksie van biografiese gegewens by die lees van 'n teks"2 maak J.C. Kannemeyer die volgende stelling:

\begin{abstract}
Om die oë te sluit vir biografiese gegewens, kan daartoe lei dat die leser so 'n werk in 'n lugleegte plaas, kunsmatig ervaar en selfs sekere struktuurlyne verwaarloos. Natuurlik sal 'n verantwoordelike kritikus versigtig te werk gaan met biografiese gegewens en bom van inleeskunde of foutiewe verbandleggings weerhou, aangesien lewensbesonderhede dikwels op 'n getransformeerde wyse in 'n kunswerk gestalte aanneem ... Ek sal dus wil beweer dat waar gegewens in die teks ons na biografiese besonderhede in verband met die kunstenaar lei, daardie besonderhede die interpretasie van die teks ten minste kan konkretiseer en ons belewing daarvan kan verruim. ${ }^{3}$
\end{abstract}

Die bevestiging dat 'n biografiese benadering van 'n teks dikwels verruimend, en selfs noodsaaklik, in die interpretasie van 'n teks kan wees, het ons gebring by die doel van hierdie artikel: hoe, en volgens watter aanduidings in die teks is die outobiografiese kode vir die leser herkenbaar, en wanneer is hierdie biografiese ondersoek noodsaaklik vir 'n adekwate interpretasie?

'n Verdere stimulus tot die skryf van hierdie artikel was enkele aannames wat Lulu Harley (1985) in haar doktorale proefskrif Outobiografie, outobiografiese roman en roman-asoutobiografie: 'n generies tipologiese ondersoek gemaak het ten opsigte van die identifikasie van die outobiografiese roman in Afrikaans. In hierdie artikel word in gesprek getree met bogenoemde proefskrif, en word aangedui wátter tekens in die teks as outobiografiese aanwysers gelees kan word, en watter tekens beskou moet word as behorende tot die domein van die konkrete outeur en dus nie relevant vir die resepsie van die teks nie. ${ }^{4}$ Meer daaroor later.

\title{
2. Die biografiese perspektief: 'n historiese oorsig5
}

'n Opvallende verskynsel in die literêre kritiek van die twintigste eeu is die sterk reaksie wat daar onder letterkundiges bestaan op die gebruik van biografiese gegewens by die

\footnotetext{
2 Aanbaling uit dié artikel met vergunning van die outeur.

${ }^{3}$ Teoretici soos Corti (1978:21), Lanser (1981:122) en Juhl (1990:89) huldig dieselfde standpunt as Kannemeyer.

4 Vergelyk ook in hierdie verband Van Coller en Van Rensburg (1982:220-221) se skematiese uiteensetting van die literére kommunikasieproses. Hulle sê onder meer die volgende aangaande die domein van die konkrete outeur: "Buite dic literêre werk as sodanig staan dic konknete outeur (byvoorbeeld S.P.D. le Roux). Van hom is sekere aspekte in die werk aanwesig, maar dit is nie wetenskaplik bepaalbaar nie; daarom staan hy self buite die literére werk en die literére ondersoek."

5 Hierdie historiese oorsig is uiteraard vereenvoudig en samevattend. Vir 'n meer volledige oorsig, vergelyk Botha (1987). Die implikasies van die biographical fallacy moet ook hier in berekening gebring word.
} 
interpretasie van 'n teks. ${ }^{6}$ In reaksie teen die negentiende-eeuse skrywers wat in hul belydenisgeskrifte en herinneringsromans dit as 'n ideaal gesien het om die 'waarheid' en die 'werklikheid' so realisties as moontlik weer te gee, en die aandag wat gegee is aan die teks as 'n psigiese projeksie van die konkrete outeur, val die aksent in die outonomistiese literatuurbeskouings op die literêre teks as 'n selfstandige en selfgenoegsame entiteit. Binne hierdie beskouing is die teks nie meer 'n dokument van die outeur nie, en is dit nie vir sy interpretasie van biografiese gegewens afhanklik nie. Jean-Paul Sartre se pleidooi was dat tekste geskryf moet word asof dit 'n natuurlike proses is, en nie die produkte van die mensdom nie; dit moet aangebied word asof dit geen outeur hét nie! (soos aangehaal deur Elliott, 1882:13). Die New Critics, in hul soektog na 'n suiwer artistieke interpretasie, sluit enige inligting aangaande die outeur, sy persoonlikheid of sy intensies by voorbaat uit. So 'n 'objektiewe' lesing lei volgens hulle tot nuwe en dieper ontginning in die meerduidigheid van poëtiese taalgebruik en die kompleksiteit van literère strukture.

Die uitgangspunte van die stilistiek op linguistiese grondslag in Afrikaans en Nederlands, en die Amsterdamse skool van Hellinga en Scholtz moet ook hier vermeld word omdat dit 'n belangrike rol gespeel het in die Afrikaanse literatuurwetenskap. Ook hier was die uitgangspunt: na die teks alleen. Die probleemstelling van hierdie benadering was taalkundig van aard, en die voorwerp van die stilistiese ondersoek was elke situasie van taalgebruik binne die teks. Die persoonlike bedoeling van die outeur is irrelevant, en so ook die die leser en sy reaksie op die teks.

Omdat die 'suiwer' literatuurondersoek van die outonomistiese bewegings weer eens 'n reaksie was op die literatuurkritiek van 'n vorige era, was dit op sigself die manifestasie van 'n uiterste. Die pro- en anti-biografiese literatuurbeskouing het dus 'n volle siklus voltooi. Sedert die sewentigerjare word die literatuurondersoek gekenmerk deur die teoretiese uitgangspunte van die Nuwe Paradigma. Een van die uitgangspunte van hierdie literatuurbenadering is dat die komplekse aard van die literêre werk vanuit 'n veelvoud van perspektiewe beskryf kan word. Die belangrikste kenmerk van hierdie opvatting is ten opsigte van die objek van die literatuurwetenskap. Die objek is nie meer of teks ó skrywer óf leser in afsondering nie, maar dit betrek die totale literêre kommunikasiesituasie met outeur, teks, leser en die hele korpus kodes wat daarmee gepaard gaan. Dit impliseer dan ook dat die ondersoek na die biografiese besonderhede van die skrywer hierbinne geakkommodeer, maar nie geëksplisiteer word ten koste van die ander komponente nie.

\section{Die outobiografiese kode in die literêre teks}

In die doelstelling van hierdie artikel is die vraag 'Hoe, en volgens watter aanduidings in die teks is die outobiografiese kode vir die leser herkenbaar?' gevra - met ander woorde, wanneer kan 'n teks binne 'n outobiografiese kode geresepteer word? Kannemeyer se reeds genoemde uitspraak, en Van Gorp se definisie van bekentenisliteratuur (outobiografiese literatuur) is hier van belang. Van Gorp (1986:45-46) se omskrywing van bekentenisliteratuur is naamlik die volgende:

Iedere vorm van literatuur waarin een schrijver voor een publiek van lezers openlijk getuigenis aflegt van zichzelf.

Kannemeyer (1989). 
Hy onderskei voorts tussen die outobiografie, 'n teks waarin die outeur sy lewe beskryf; memoirs, waarin 'n korter tydperk of 'n periode in die lewe van die outeur beskryf word; die dagboek; en die outobiografiese roman. Laasgenoemde kategorie bevat werklike én verbeeldingselemente, dit is 'n teks waarin die skrywer deur 'n spel met die konvensies van die outobiografie 'n fiktiewe pseudo-outobiografiese relaas lewer.

Dit is belangrik om daarop te let dat Van Gorp nie met hierdie definisie die outobiografie omskryf nie, maar die breër genre van bekentenisliteratuur betrek. Vir die doel van hierdie artikel is sy omskrywing van die outobiografiese roman belangrik, veral die kenmerk dat dit 'n vorm van literatuur is waarin die skrywer openlike getuienis van homself aflê deur 'n spel met outobiografiese konvensies. Ook Kannemeyer se aanname, dat die gegewens in die teks na die biografiese besonderhede van die kunstenaar moet heenlei, is veral van belang.

Die gevolgtrekking wat gemaak kan word, is dat die outeur self sekere tekens van 'n outobiografiese lesing in sy teks gee, en dat sy intensie rekonstrueerbaar is. Wanneer die outobiografiese verband tussen outeur en karakter gelè is, is dit nodig dat hierdie sleutel tot die teks ontgin, en binne 'n outobiografiese kode geresepteer word.

Daar word vervolgens kortliks gekyk na bepaalde metodes waardeur die outeur sy outobiografiese intensies in die teks kan laat blyk. Die voor die hand liggende vorme van outobiografiese literatuur, die outobiografie, dagboek en memoirs word nie in hierdie ondersoek betrek nie.

\subsection{Die outeursnaam}

\subsubsection{Direkte ooreenkoms tussen outeurs- en karakternaam}

Die mees opvallende, en duidelikste teken van 'n outobiografiese kode in 'n teks, is dat 'n karakter met dieselfde naam as die outeur van die teks benoem word. Voor die hand liggende tekste in Afrikaans waarin hierdie tegniek gedemonstreer word, is André Letoit se romans Somer 11 (1985) en Suidpunt-jazz (1989), en enkele verhale in Koos Prinsloo se kortverhaalbundels Jonkmanskas (1982) en Die hemel help ons (1987).

André Letoit se roman Somer 11, het nie net intertekstuele kommentaar op C.M. van den Heever se gelyknamige roman ten doel nie. Met die gebruik van die ek-verteller in 'n outobiografiese gedaante, 'n verteller wat gestalte vind in 'n verskeidenheid identiteite en stemme, word die ervaringwêreld van die skrywende persona/karakter ontgin.

Dieselfde procédé word ook in Suidpunt-jazz gevind. Dié roman met sy absurditeite is, volgens die titelblad, "'n roman vir Suid-Afrika vandag". In die toonaard van die klug, die parodie en die pastiche word politiek, godsdiens, geskiedenis, seks, apartheid, Afrikanerskap, en die literêre kritici betrek. Te midde van 'n hutspot absurde gebeure is die verteller/skrywer in sy persona teenwoordig omdat hy terselfdertyd die karakters Fanie, Johan, Libido, André Letoit, én die reïnkarnasie van Piet Retief is. Teen wil en dank word die leser ook 'n medepligtige aan die skryfproses, omdat sy (tradisionele) behoeftes en lesersingestelheid geformuleer, maar ook geridikuliseer word, en hy ook 'n rol te speel het in die teks-in-wording. 
Met die direkte identifikasie van die skrywer as 'n karakter in sy teks, formuleer die outeur die tema van hierdie twee Letoit-romans: die skrywer in sy alomteenwoordige, manipulerende rol as maker en belewer van 'n teks.

Die funksies van die konkrete en die abstrakte outeur in die literêre teks word in Koos Prinsloo se outobiografiese kortverhale geëksploiteer. Hierdie skrywer maak nie net van sy eie voornaam gebruik om die verband tussen die outeur en sy karakter 'Koos' uit te wys nie, hy maak ook van ekstra 'bewyse' soos familiekronieke, datums, en selfs foto's gebruik. Hierdie dokumentêre werkwyse staan te midde van die postmodernistiese literatuuropvatting van die tagtigerjare wat die tradisionele grense tussen genres bevraagteken, en waar die teks ' $n$ jukstaponering van die dokument en fiksie is om 'n nuwe, versplinterde, werklikheid te skep.

Die biografiese verwantskap in Prinsloo se verhale wat direk onder die leser se aandag gebring word, kry egter 'n relativerende en ironiese dimensie as die verteller in een van die verhale ("Die jonkmanskas") homself tot die status van die abstrakte outeur verhef, en sy lesers die pertinente voorskrif gee om die verhaal as fiksie te lees (Prinsloo, 1982:72). Die outeur/karakter demonstreer sy ambag as skrywer, en maak op 'n selfbewuste wyse die leser telkens daarop attent dat sy verhaal as metatekstuele verhaal gelees moet word. In hierdie verhale demonstreer Prinsloo ook die ontologiese twyfel van die postmodernistiese teks. Sy outobiografie is nie outobiografies nie, sy reisverhaal is nie 'n reisverhaal nie, Koos is nie 'Koos' nie. Die spel-element met outobiografiese konvensies is 'n duidelike kode in Prinsloo se werk.

Die artistieke inkleding van die outobiografiese stof in Prinsloo se werk bring ten slotte die skrywer sowel as die leser in 'n dinamiese konfrontasie met die probleem van die verhouding tussen kuns en werklikheid.7

\subsubsection{Indirekte ooreenkoms tussen outeurs- en karakternaam}

Die biografiese ooreenkoms tussen die outeur en 'n karakter in sy teks is nie altyd in 'n een tot een-verhouding nie. In sommige tekste is daar nie direkte getuienis van die konkrete outeur se persona nie, maar wel, volgens Van Gorp se eis, openlike getuienis. 'n Bundel kortverhale waarin hierdie indirekte ooreenkoms tussen outeur en karakter afleibaar is, is J.M. Gilfillan se Van stiltes en stemme (1989).

Van stiltes en stemme is nie ' $n$ eenheidsbundel nie, maar die afsonderlike verhale word tog onderling verbind deur die terugkerende motief van geweld en die sentrale plek wat die karakter 'Rietjie/Margaritha' inneem. Nog 'n belangrike skakel in die bundel is die ruimtelike plasing van die verhale. Die meeste verhale speel af in swoel, tropiese Natal - in 'n stad "wat groen is van voortwoekerende plantegroei" (Gilfillan, 1989:38).

Vyf opeenvolgende verhale in die bundel ${ }^{8}$ vorm ' $n$ kort siklus waarin die dogtertjie Rietjie, en later die vrou Margaritha die sentrale karakter is. In die verloop van hierdie verhale

\footnotetext{
7 Vir 'n voliedige uitecnsetting van die biografiese kode in Prinsloo se "Die jonkmanskas", vergelyk Botha, 1987:81-103.

${ }^{8}$ Dié vyf verbale is: "Dic troudag", "Taalles", "Huisbesoek", "Sprokie" en "Partytjie" .
} 
ontplooi die lewensverhasl van Rietjie/Margaritha, 'n vrou wat as dosent aan 'n umuse universiteit verbonde is. Hier moet sy die 'taal van die onderdrukker', Afrikaans, aan swart studente doseer, en ervaar sy eerstehands die politieke opstand en geweld wat in die SuidAfrika van die tagtigerjare 'n historiese werklikheid was.

Die leser wat bekend is met die historiese persoon Rita Gilfillan, ('n lektrise in Afrikaans aan die Universiteit van Durban-Westville, en daarom betrokke by die Afrikaanse literatuursisteem) kan maklik die indirekte verwantskap tussen die konkrete outeur en die sentrale karakter rekonstrueer. Hierdie verwantskap is nie net herleibaar uit die karakter Margaritha se benoeming in 'n verwante (maar verskuilde) vorm van die outeursnaam nie, maar ook uit die konteks van die omstandigheidsgetuienis: die ruimte (Durban) en die belewende karakter se professionele hoedanigheid (dosent). Die leser wat nié bekend is met hierdie biografiese besonderhede nie, sal nie noodwendig die teks verkeerd interpreteer nie, omdat die outobiografiese kode nie as die dominante kode geaktiveer word nie. Kannemeyer het ook (in die aanhaling hierbo) daarop gewys dat lewensbesonderhede op 'n getransformeerde wyse gestalte aanneem. In hierdie bundel verhale gaan dit nie oor geweld as sodanig nie, maar oor die vroulike belewing van geweld in verskeie vorme. Dit is egter duidelik dat hierdie verhale, volgens Van Gorp se benadering, openlike getuienis van die outeur aflê. Die outeur kon ewe maklik die kind/vrou se naam, en die ruimtelike plasing verander het om enige outobiografiese verband te ontken. Wanneer die biografiese besonderhede egter in ag geneem word binne die konteks van die bundelkode (geweld, en die grense tussen kultuurgroepe), het dit die funksie om die leser se ervaring te konkretiseer en te verruim. Met die outobiografiese inset word hierdie bundel getransformeer tot 'n belangrike eietydse dokument - 'n teks wat die geweld van die Suid-Afrikaanse samelewing, en spesifiek die gewelddadige situasie in Natal, op artistieke wyse dokumenteer. Dit is asof die outeur met hierdie werkwyse wil sê: ek was dáar, dit is méér as net die artistieke weergawe van die onrus.

\section{Die neweteks}

In tekste waar daar geen ooreenkoms tussen die outeurs- en karakternaam is nie, kan 'n biografiese verband tussen outeur en karakter ook deur die neweteks ${ }^{9}$ van 'n teks bevestig word. Die eis waaraan die verband tussen outeur en karakter moet voldoen, is dat dit openlik moet wees, met ander woorde, die intensie van die outeur moet sodanig wees dat die leser die verband kan rekonstrueer, en dit moet tekstueel verantwoordbaar wees.

'n Jeugverhaal wat deur sy openbarende neweteks die outobiografiese ooreenkoms tussen outeur en karakter lè, is Uys Krige se Die droom. Hierdie verhaal het oorspronklik in Engels verskyn as 'n verhaal in die bundel The dream and the desert (1953), ${ }^{10}$ en is in 1989 in Afrikaans vertaal deur Ina Rousseau. Op die agterblad van die Afrikaanse uitgawe van hierdie verhaal is 'n uittreksel uit 'n brief wat Uys Krige in 1953 aan sy ma, Sannie Uys, geskryf het, afgedruk. In hierdie brief sê die skrywer (Krige) onder andere:

\footnotetext{
${ }^{9}$ Vanweè die betekenisdraende funksie wat dit in sekere tekste het, word 'ekstra-tekstuele' gegewens soos motto's, voetnote, opdragte, skadeloosstellings en plek-/tydaanduidings cnsovoorts as die neweteks van die betrokke literêre werk beskou. Kyk ook voetnoot 12.

${ }^{10}$ Hierdie bundel, The dream and the deser, (1953) bevat vertaalde stukke uit Afrikaans en oorspronklike Engelse verhale.
} 
Ek is bly dat Mammie so baie van "Die droom" hou. Eintlik is ek diep ontroer deur Mammie se woorde. Juis omdat daar so baie van $\mathrm{u}$ in die verhaal is: Ons is die hoofkarakters daarin ...

Saam met dié openlike bevestiging van outobiografiese oorsprong, verskyn ook die volgende uitgewersnota wat deel uitmaak van die neweteks:

Die droom is biografies en het oorspronklik in Engels verskyn in The dream and the desert.

Met hierdie verklarende neweteks word die outobiografiese karakter van die verhaal bevestig. Omdat 'n funksionele neweteks 'n betekenisdraende funksie in die teks het, ${ }^{11}$ en dikwels ' $n$ belangrike interpretasiesleutel is, moet die leser hierdie aanwysing as 'n betekenisdraende teken hanteer.12

Die leser wat bekend is met Uys Krige se biografiese besonderhede, sal sy persona dadelik in die karakter van die protagonis Jannie herken: 'n lewenslustige, maar sensitiewe knaap wat op sy gelukkigste is as hy 'n bewonderende gehoor rondom hom het, en dol is oor rugby (Krige was self 'n kranige rugbyspeler, en sy pa was die legendariese Springbok Japie Krige).

Die droom is die verhaal van 'n jong kind wat die wreedheid van die dood moet verwerk as daar binne 'n kort bestek vyf van sy familielede doodgaan. Die mees traumatiese ervaring is egter die dood van sy bababoetie, 'n prematuur-gebore baba wat kort na sy geboorte sterf. Hierdie verhaal, wat deur resensente beskou word as 'n klassieke jeugverhaal, is nie net een van die min verhale in Afrikaans wat die kind se doodsbelewenis as tema het nie, dit is 'n sleutelverhaal in Krige se oeuvre. Hennie Aucamp (1989:14) stel dit so:

"The dream" (is) uitstekend as verhaal, maar ook 'n sleutel tot die skrywer Uys Krige. Want "The dream" is onbeskaamd outobiografies ... Alles wat wesenlik is in Uys Krige se lewe en werk kan hierin teruggevind word.

Johann Lodewyk Marais sê in sy artikel "'n Kort herbetragting van Uys Krige se prosa met verwysing na "The dream" as sleutelteks" (1988) dat die doodsgedagte, die verering van die moederfiguur, natuurbeelding, en die ervarende ek wat kenmerkend van Krige se dokumentêre tekste is, asook die vermenging van die surrealistiese en die naïewe, van die belangrikste kenmerke van Krige se prosa is. Die slotsom waartoe hy (Marais, 1988:27-28) kom, is:

Waar soveel elemente wat kenmerkend van Krige se werk in een knap verhaal soos "The dream" voorkom, is dit duidelik dat ' $n$ mens te doen het met 'n sleutelteks binne (sy) oeuvre. Dit is die soort teks wat selde in enige skrywer se oeuvre voorkom en dit is om hierdie rede iets besonders.

\footnotetext{
"Vir 'n meer volledige uiteensetting van die ondersteunende en betekenisdraende funkies van dic newetcks, vergelyk Botha (1989:35-44).

${ }^{12}$ Die term leë teken word vir die doeleindes van hierdie artikel omskryf as dié tekens wat binne 'n bepaalde kode of konteks nie geaktiveer word nie, maar binne enige ander kode of konteks geaktiveer kan word tot 'n betekenisdraende of gelaaide teken. $\mathrm{Al}$ is 'n teken binne 'n bepaalde kode leeg, of ongemerk, is dit per definisie betekenisvol in sy funksie om uit te wys na iets anders, en is dit daarom altyd sigbaar of aantoonbaar in 'n teks. 'n Leë teken moet dus onderskei word van die oop plekke in die teks wat betekenisvolle gapings is, en wat deur die leser interpretatief gevul moet word. Wanneer daar sprake is is van 'n leê teken, verwys dit na 'n onfunksionele teken. 'n Betekenisdraende teken is 'n funksionele teken. Vergelyk ook Botha (1987).
} 
Die outobiografiese verband wat deur die neweteks bevestig word, het in hierdie verhaal dus die funksie om die temas en tegnieke van 'n groter oeuvre te sinjaleer.

'n Jeugverhaal wat ook deur middel van sy neweteks 'n biografiese verband le, is Wynand se oorlog van Ria Jordaan (1989). Dit is 'n verhaal wat handel oor 'n jong Afrikanerkind, Wynand, se ervaringe van die Vryheidsoorlog. Hierdie verhaal word gebaseer op die vertellings van die skryfster se moeder oor haar (die skryfster) se oom Wynand gedurende die oorlogsjare. Hierdie biografiese besonderhede word op die omslagteks gegee, en is ook rekonstrueerbaar uit die adressaat van die boek. Die boek word opgedra aan die skryfster se ma, en lui so: "Opgedra aan my ma: Wynand was haar broer" (Jordaan, 1989:iv). Met hierdie teks word daar nie 'n outobiografiese verband gelê tussen die outeur van die teks en 'n karakter nie, maar 'n biografiese verbintenis tussen die karakter en 'n historiese persoon op wie se ervaringe die verhaal berus. Wat ook hier ter sake is, is die historiese persoon se outobiografiese verband met die outeur. Hierdie inligting, dat daar wél 'n persoon genaand Wynand was, en dat die gebeure op feite gebaseer is, skep geloofwaardigheid en 'n vertroudheid by die (jong) leser. Deur hierdie biografiese inset het 'n interessante, en dikwels onbekende deel van die Afrikaner-geskiedenis vir die jong leser realiteit geword.

\title{
33 Outobiografiese inhoud
}

In die voorgaande afdeling is daarop gewys dat die neweteks van Uys Krige se Die droom op pertinente wyse die leser daarop bedag gemaak het dat die verhaal die outeur se outobiografiese relaas van 'n jeugervaring is, waarin hy (Uys Krige) en sy ma (Sannie Krige) die hoofkarakters is. Die leser moet egter onthou dat hierdie teks 'n vertaalde weergawe is, en dus in 'n totaal nuwe gedaante aan die leserspubliek bekend gestel is. Dit word nie net vir die eerste keer as 'n Afrikaanse verhaal aangebied nie, maar ook as 'n afsonderlike teks. Die oorspronklike verhaal "The dream" het in 'n versamelbundel verskyn, (vergelyk voetnoot 10) en ook sónder die verklarende neweteks wat die Afrikaanse uitgawe kenmerk. Dit is dus interessant om die resepsie van die verskillende uitgawes ten opsigte van hul aanspraak op outobiografiese status te vergelyk.

In die reeds genoemde artikel van Johann Lodewyk Marais (wat in 1988 gepubliseer is) was die vertaalde weergawe (Die droom) nog nie beskikbaar nie. Marais (1988:27) koppel die outobiografiese insette van die teks aan die outobiografiese inhoud. Hy sê naamlik:

\begin{abstract}
'n Verdere aspek wat in "The dream" van belang is, is die sterk outobiografiese elemente: die ruimte waarin die karakters geplaas is (Stellenbosch, Onrustrivier en Kaapstad, asook verwysings na die plaas), die geesdrif vir rugby en die feit dat Jannie se vader, Japie Kotze, 'n Springbokrugbyspeler was net soos Uys Krige s'n. Voorts is die besondere verhouding tussen Jannie en sy (Engelse) moeder tekenend van die verhouding tussen Krige en sy moeder, en selfs die name van die verskillende karakters toon dikwels 'n opvallend biografiese verwantskap met die van enkele Kriges.
\end{abstract}

Die outobiografiese verband van "The dream" word dus sonder die verklarende neweteks van die Afrikaanse weergawe bevestig, en wel deur die outobiografiese inhoud. Dit is ook opvallend dat hierdie outobiografiese aanspraak berus op name (die van familielede, soos byvoorbeeld die ooreenkoms tussen die protagonis se pa, Japie Kotze en Krige se pa Japie); op die ruimte (by name Stellenbosch, Onrust ensovoorts), en gebeure (die pa se Springbokkleure, en die dood van die boetie). Hierdie feite is histories bekend.

Soos in die vorige afdeling uitgewys is, is die funksie van die outobiografiese verbandlegging in hierdie teks om dit as sleutelteks in 'n oeuvre te eien. Dit het ook die funksie om 'n 
direkte, en eerlike ervaringswerklikheid weer te gee - 'n belangrike kenmerk van jeuglektuur (Meyer, 1988:20).

\subsection{Die intertekstuele konteks}

In sy artikel "Die teruggekeerde Opperman: Die funksie van biografiese gegewens by die lees van 'n teks" wys J.C. Kannemeyer daarop dat die outobiografiese gegewens wat in Opperman se Komas uit ' $n$ bamboesstok ter sprake is, veral deur die intertekstuele verband tussen die gedig "Kaapse skeepswerf" en die res van die gedigte in dié bundel ontsluit word. Hy maak die aanname dat die volledige betekenis van die gedig eers vir die kreatiewe leser duidelik word as hy ander gedigte in die bundel (ook enkele ander gedigte uit Opperman se oeuvre) by die leesaksie betrek, sodat die volle biografiese lading uit die netwerk van verhoudinge spreek (Kannemeyer, 1989). Hy maak voorts die belangrike stelling dat die intertekstuele betekenis wat deur die leser gerekonstrueer word, reeds inherent in die enkele teks aanwesig is; die leser moet dit net met die konkretiserende en verbandleggende funksie van sy intertekstuele ondersoek vir homself ontdek. Die oorspronklike eis, dat daar tekens of gegewens in die teks moet wees wat die leser na biografiese besonderhede lei, word dus weer eens hier beklemtoon.

'n Intertekstuele relasie wat die leser attent maak op 'n biografiese werkwyse is ook te vinde in die kortverhaalbundel van André le Roux, Sleep vir jou 'n stoel nader. In hierdie geval is die belangrikste biografiese verbande nie dié tussen outeur en verhaalgebeure/karakters nie, maar die (rekonstrueerbare) outensiteit van verhaalgebeure, en die outofiksionele verwerking van hierdie gebeure. Die doel van die outeur was in hierdie geval nie om outobiografiese verhale te skryf nie, maar om die leser te konfronteer met die postmodernistiese verhouding tussen kuns en werklikheid. Die leser kry hier gedemonstreer hoe die rol van verdigting en vormgewing aan faksie ${ }^{13}$ sy literêre selfstandigheid verleen.

Die motto van hierdie bundel kortverhale, 'n aanhaling van die Poolse skrywer/akademikus Jerzy Kosinki, lui so:

This is about memory, and since memory is fiction, call it autofiction. Autofiction (or "eye to I", as it is sometimes called) is a literary genre, generous enough to let the author adopt the nature of his fictional protagonist - not the other way round (Le Roux, 1987:v).

Met hierdie motto klassifiseer die outeur self die teks as outofiksie. Gebeure word losgemaak van hul feitelike oorsprong, en omdat dit nou bloot as 'n kennisinhoud deel is van die outeur se verwysingsraamwerk, kan die gebeure opnuut geskep word: as outofiksie.

Die blakerteks op die agterblad van hierdie bundel is 'n collage van joernalistieke indrukke. Die lettertipe is dié van 'n tikmasjien, en die teks word getoon met tikfoute en al. Die inligting wat die leser uit hierdie blakerteks kry, is onder meer die volgende:

" 'n kort tematiese aanduiding: "Dit gee 'n onthutsende beeld van ons land en sy mense",

" 'n tipering van die styl as "joernalistieke waarneming",

\footnotetext{
${ }^{13}$ Faksie word beskou as dokumentêre realisme, waar dic teks deur middel van bepaalde narratiewe tegnieke die dokument, of dokumentère gegewe, omskep tot 'n eie en 'n nuwe werklikheid. Vgl. Botha (1987:82).
} 
" 'n tipering van die styl as "joernalistieke waarneming",

" die outeur se beroep: "verslaggewer en 'kunsredaksielid' van Die Burger".

Hierdie bevestiging van 'n joernalistieke agtergrond word 'n belangrike intertekstuele verwysing. 'n Agttal foto's (dus feitelike afbeeldings) is ook deel van die buitebladontwerp van Sleep vir jou ' $n$ stoel nader. Dat hierdie foto's 'bewysstukke' is van die verhale wat in die bundel opgeneem is, word al gou duidelik wanneer die verhale gelees word: die karakters van die stories is dáár in hul afbeelding: Doreen, Sidney, Matjiesfontein se komeetkykers, die mense van Goudini-Spa, die daggarokers verhul in 'n rookwolk. Met hierdie blakerteks erken die outeur op implisiete wyse die joernalistieke oorsprong van sy verhale: sy joernalistieke ondervinding word vermeld, die lettertipe van die blakerteks is in joernalistieke gedaante, en Huisgenoot-fotograwe David Briers en Corrie Hansen word in die kolofon (die uitgewersruimte) erken. Die kolofon mak tradisioneel nie deel uit van wat Susan Lanser die "textual voice" noem nie (Lanser, 1981:122) en is dus nie genoegsame, of tekstuele bewys vir 'n biografiese aanname nie. Hierdie fotograwe tree egter ook op as karakters in die verhale, en hierdie tekstuele verbintenis maak dat die kolofon wel as 'n betekenisdraende teken beskou moet word (vgl. voetnoot 12). Dit is algemeen bekend dat die (meeste) verhale wat in hierdie bundel verskyn, hulle feitelike en joernalistieke pendante het wat as tydskrifartikels in die Huisgenoot verskyn het (daarom die erkenning aan die fotograwe). Vir die doel van hierdie artikel is dit noodsaaklik om hierdie intertekstuele verband uit te wys, want dit vestig die leser se aandag op die biografiese oorsprong van die verhale. Die joernalistieke verwagtingshorison van feitelikheid wat hierdeur opgebou word, word egter gerelativeer deur die gebruik van die motto wat saam met die buiteblaaie deel vorm van die neweteks. Die leser kry deur die motto die voorskrif dat hy die verhale nie moet lees as joernalistieke reportage (feite) nie, maar as outofiksionele tekste. Die joernalistieke oorsprong van die verhale, met al die eise van objektiwiteit en feitelikheid is oorboord gegooi, en met dieselfde gegewens word 'n nuwe artefak, 'n nuwe genre geskep.

Een van die funksies van die outobiografiese besonderhede kan dus in hierdie unieke geval beskou word as 'n meganisme om 'n tekssoort, outofiksie, aan die leser te demonstreer. Die tekste self omvat egter veel mér as blote demonstrasie van 'n tekssoort.

\section{Die outobiografiese teks: 'n kritiese beskouing}

In die voorafgaande gedeelte van hierdie artikel is op enkele metodes gewys waardeur die outobiografiese verband tussen die teks en konkrete outeur herkenbaar is. Dit is ook deurgaans beklemtoon dat hierdie verbande tekstueel bevestig moet word om te verhoed dat die leser hom aan foutiewe verbandlegging skuldig maak.

In haar doktorale proefskrif Outobiografie, outobiografiese roman en roman-as-outobiografie: 'n generies-tipologiese ondersoek omskryf Lulu Harley die kenmerke van die outobiografiese roman ${ }^{14}$ soos volg:

Die identiteit van skrywer en hooffiguur ... is tegelyk reëel en twyfelagtig. Dubbelsinnigheid en verobjektivering vorm hier sleutelbegrippe; en,

${ }^{14}$ Vir die doeleindes van hierdie studie word daar net op Harley se definisie van die outobiograficse roman gekonsentreer. 
In die outobiografiese roman is enige kongruensie wat daar mag bestaan tussen ware gebeurtenisse en die wat in die teks beskryf word, irrelevant. Die hooffiguur redeneer nie direk, bv. by wyse van naamgewing, na 'n bistoriese persoon nie. Enige verband wat tussen skrywer en protagonis mag bestaan, sal op grond van tekseksteme gegewens aangebring moet word (Harley, 1985: iv,2-3; my kursivering.)

Die aanname dat biografiese verbande op grond van tekseksterne gegewens gelê moet word, staan lynreg teenoor die standpunte van Van Gorp en Kannemeyer soos dit in hierdie artikel gebruik is: Kannemeyer se eis dat die teks self die sleutel tot 'n outobiografiese lesing moet gee, sluit aan by die van Van Gorp wat klem lê op die openlike, of die rekonstrueerbare verband. Daar is ook reeds in hierdie artikel daarop gewys dat die outobiografiese verbande tussen teks en werklikheid wél 'n verskeidenheid funksies het - en nie sonder meer as "irrelevant" (Harley in die aangehaalde gedeelte) afgeskryf moet word nie.

In haar bespreking van Afrikaanse outobiografiese romans tipeer Harley drie tekste as 'outobiografiese romans': Sy kom met die sekelmaan van Hettie Smit, 18-44 van Etienne Leroux en Klaaglied vir Koos van Lettie Viljoen. Met die tipering van laasgenoemde teks kan ek nie ten volle saamstem nie.

Harley maak die aanname dat die titel van Lettie Viljoen se novelle Klaaglied vir Koos 'n intertekstuele relasie met Marnix Gijsen se roman Klaaglied om Agnes oproep. 'n Inhoudelike en generiese aansluitingspunt word deur die ooreenkoms van titels gevind wat eersgenoemde novelle dan, aldus Harley, tipeer as outobiografiese roman/novelle. Met die redenasie tot sover kan daar myns insiens nie fout gevind word nie, behalwe dat daar mér as net 'n intertekstuele verband tussen titels nodig is om 'n teks se aanspraak op outobiografiese insette te regverdig. Harley gaan egter voorts ook van die standpunt uit dat Klaaglied vir Koos getipeer kan word as 'n outobiografiese roman omdat die gebruik van 'n skuilnaam (Lettie Viljoen, pseudoniem vir I. Scholtz) "'n outobiografiese oorsprong vir die novelle (suggereer)" (Harley, 1985: 3, 178 e.v.). Dit is 'n aanname wat, weer aldus Harley, in 'n onderhoud met die skryfster 'erken' is. Harley se argumentasie betrek nie die relevante argumente nie, en is myns insiens nie haalbaar nie, en wel om die volgende redes:

Eerstens kan die gebruik van 'n skuilnaam nié sonder meer, sonder enige tekstuele aanwysings of bevestiging, 'n outobiografiese oorsprong impliseer nie. Van Gorp (1986:45-46) se definisie van outobiografiese literatuur is dat dit "iedere vorm van literatuur (is) waarin een schrijver voor een publiek van lezers openlijk getuigenis aflegt van zichzelf" (my kursivering). Van openlike getuienis deur die konkrete outeur is daar in die onderhawige novelle nie sprake nie; trouens, die skuilnaam dien soos in alle gevalle waar skuilname betrokke is, die doel om die outeur se identiteit, vir watter rede ook al, te verdoesel.

Klaaglied vir Koos word nié as 'n teks met outobiografiese pretensies aangebied nie. Die gebruik van 'n skuilnaam kan in hierdie geval ook júís daarop dui dat 'n persoonlike lewenservaring of -geskiedenis (al dan nie) op 'n getransformeerde wyse in 'n teks met fiksionele aansprake aangebied word, en dat die teks daarom geregtig is op sy fiksionele status - ten spyte van wat die skrywer se persoonlike ervaringe mag wees.

In die tersaaklike onderhoud met die skryfster (Jansen, 1984:21) was daar geen bevestiging dat bepaalde of spesifiek-genoemde gebeure in die novelle 'n outobiografiese basis vir die novelle sou vorm nie. Die aanhaling wat Harley in die onderhoud uitlig as 'n outobiografiese 'bevestiging' lui so: "Die leser kan seker daarvan uitgaan dat dit sny met 
my werklikheid, maar ek sê nie teen watter hoek nie ..." Hierdie aanhaling is juis ontkenning van outobiografiese verantwoordelikheid, omdat die skrywer die reg voorbehou om 'n verbintenis te maak tussen teksgebeure en outobiografiese feite. (Dit staan in skerp kontras met die outobiografiese bekentenisse wat byvoorbeeld deur Uys Krige gemaak is om sy teks te tipeer.)

Daar moet ook onthou word dat élke skrywer vanuit sy persoonlike ervaringsveld insette in 'n teks lewer, en in dié ruim sin kan elke denkbare teks dan gesien word as 'n 'outobiografiese' teks, en is die fiktiwiteit van 'n teks nie meer ter sprake nie.

Die identifikasie van die outobiografiese kode lè op ander terreine as dié van skuilname en vae stellings, soos reeds in hierdie artikel aangedui is. 'n Outobiografiese inset mót uiteindelik tekstueel verantwoord word - gegewens in die teks moet (in die woorde van Kannemeyer) die leser na die (konkrete) outeur heenlei - wat nie die geval is met Klaaglied vir Koos nie. 'n Kenmerk van hierdie novelle is juis die ongeïdentifiseerde vroulike verteller wat in die verhaal as protagonis optree. En as daar enigsins 'n verband gelê sou kon word, sou dit wees tussen die vroulike verteller en die fiktiewe 'persoon' van Lettie Viljoen.

'n Verdere argument wat Harley aanvoer om Klaaglied vir Koos as outobiografiese roman te tipeer, is dat die skrywersteks, wat die "skrywersnaam, kopiereg en opdrag" bevat, betekenisvol is ten opsigte van die skrywer as historiese persoon (Harley, 1985:178). In hierdie ruimte word die kopiereghouer (I. Scholtz) se naam gevind, en Harley koppel dit (tereg) aan die skrywersnaam van Lettie Viljoen. Met behulp van Sensal bepaal Harley voorts dat Ingrid Scholtz met die persoon Anton Scholtz getroud was, en koppel die persoon van die adressaat (Anton) aan hom. Die fundamentele fout wat Harley met hierdie 'speurtog' maak, is om outobiografiese betekenis te heg aan buite-tekstuele gegewens. Wat Harley die 'skrywersruimte' (dus teks) noem, is inderdaad nié die skrywersruimte, en daarom deel van die teks nie. In hierdie geval moet daar onderskei word tussen die abstrakte outeursteks (die hoofteks), die konkrete outeursteks (alle niefunksionele ekstra-tekstuele gegewens soos adressate, ens.) en die uitgewersteks of kolofon (wat dikwels nie-funksionele inligting soos byvoorbeeld lettertipes, bevat). In 'n artikel getiteld "Die funksionaliteit van die neweteks" (Botha, 1989) is reeds daarop gewys dat elemente uit die konkrete outeursteks of kolofon 'n belangrike deel van die hoofteks kán word indien dit 'n betekenisdraende funksie ten opsigte van die abstrakte outeursteks vervul. In só 'n geval kry dit die status van neweteks, en kan die inligting wat daarin vervat is, op wetenskaplike wyse verantwoord word. Wanneer dit egter nié 'n betekenisdraende funksie vervul nie, bly dit deel van die konkrete outeursruimte en het dit net persoonliksentimentele of kuriositeitswaarde.

Die persona wat in die adressaat van Klaaglied vir Koos aangespreek word ("vir Anton") figureer nêrens deur 'n direkte of indirekte tekstuele verbintenis in die teks nie. Die adressaat het dus nie 'n funksionele rol in die teks nie, en word beskou as 'n leë teken en deel van die konkrete outeursruimte (kyk ook die opmerkings by voetnoot 12). Harley se werkwyse is om die gegewens van die konkrete outeursruimte en kolofon, sonder tekstuele bevestiging by die argumentasie te betrek, en as bewys van 'n outobiografiese verband aan te bied. Vir alle praktiese doeleindes is Harley se outobiografiese verbandlegging nie relevant nie, omdat sy van leë tekens gebruik maak (die adressaat), en uitgewersinligting (kolofon) wat in élke teks aanwesig is. 
'n Argumentasie ten gunste van 'n outobiografiese kode is nie volledig as die sknwersintensie nie ook betrek word nie. 'n Outobiografiese roman kan myns insiens alleen as sodanig getipeer word as dit as sodanig aangebied word, en indien dit nie die geval is nie, moet die fiktiewe aanbod eerbiedig word. Die skrywer se intensie word openbaar gemaak deur tekens in die teks, of tekens wat die teks op funksionele wyse begelei. Dit is egter ook moontlik dat die teks eers op 'n latere stadium, en in 'n verandere resepsieklimaat (soos in die geval van Krige se Die droom) as 'n outobiografiese teks aangebied word, hetsy deur die uitgewer, of deur openbare getuienis wat beskikbaar gestel word. 15 Hierdie tekens, en hoe verskillende skrywers op innoverende wyse daarvan gebruik maak, is reeds bespreek onder die opskrif Die outobiografiese kode in die literêre teks in hierdie artikel.

Klaaglied vir Koos vertoon nie tekens van 'n outobiografiese skrywersintensie nie. Dit word ook nie volgens 'n outobiografiese afspraak aangebied nie. Die skrywersintensie dui in hierdie geval op 'n fiktiewe, en nie 'n outobiografiese aanbod nie.

\section{Slotsom}

Dit het duidelik uit die bespreking van die gekose tekste geblyk dat 'n funksionele, en korrekte, toepassing van die biografiese kode 'n verruimende interpretasie van 'n teks tot gevolg het. Trouens, binne die kontemporêre literatuurkritiek neem dit 'n belangrike, en dikwels noodsaaklike plek in. Terselfdertyd moet die kritikus of leser wat hom hieroor wil uitlaat, besef dat hy hom op die gevaarlike terrein van foutiewe verbandlegging kan bevind. Die bepaling van die outeursintensie is hier van deurslaggewende belang.

Met die vryheid wat die leser het, kan hy 'n interpretasie maak, maar dan op grond van grense wat deur die teks self getrek word.

\section{Bibliografie}

Aucamp, Hennie 1989. Afrikaans 'n kleinklassiek ryker. Die Burger : 14. Nov. 11.

Botha, Riana 1987. 'n Onderskeiding tussen leë en betekenisdraende tekens in die literêre kommunikasieproses, geillustreer aan die hand van Die jonkmanskas van Koos Prinsloo. Blocmfontein. (Verbandeling (M.A.) - UOVS.)

Botha, Riana 1989. Die funksionaliteit van die neweteks. Stilet, 1(2): 35-44, Julie.

Corti, Maria 1978. An intraduction to literary semiotics. Bloomington, London : Indiana University Press. Elliot, Robert, C 1982. The literary persona. Chicago and London: The University of Chicago Press.

Hambidge, Joan 1990. Die somber muse. Kaapstad : Jutalit.

Harley, LJ. 1985. Outobiografie, outobiografiese roman en roman-as-outobiografie: 'n genteries-tipologiese ondersoek. Pretoria (Proefskrif (D.Litt) - UP.)

Hugo, Daniel 1986. Die boek Daniel. Kaapstad, Pretoria : Human en Rousseau.

Gilfillan, J.M. 1989. Van stiltes en stemme. Kaapstad, Pretoria : Human en Rousseau.

Jansen, Ena 1984. 'n Vrou het tog dubbele fantasieë. Beeld : 2. Des. 13.

Jordaan, Ria 1989. Wynand se oorlog. Kaapstad : Tafelberg.

Juhl, P.D. 1980. Interpretation. An essay in the philosophy of literary criticism. Princeton, New Jersey: Princeton University Press.

Kannemeyer, J.C. 1978. Geskiedenis van die Afrikaanse literatuur I. Kaapstad : Academica.

\footnotetext{
${ }^{15}$ Harley maak wel van sulke openbare getuienis gebruik in haar tipering van die ander twee romans wat sy as outobiografiese romans beskou (vgl. Kannemeyer 1978:456 en 1983:366). Volgens my wete is daar wat Lettie Viljoen se roman betref, nog nie getuienis van dieselfde aard beskikbaar nie.
} 
Kannemeyer, J.C. 1983. Geskiedenis van die Afrikaanse literatuur II. Kaapstad : Academica.

Kannemeyer, J.C. 1989. Die teruggekeerde Opperman : Die funksie van biografiese gegewens by die lees van 'n teks. Ongepubliseerde artikel. (Met vergunning van dic outeur.)

Krige, Uys 1989. Die droom. Vertaal deur Ina Rousseau. Vlaeberg : Vlaeberg.

Krige, Uys 1953. The dream and the desert. London : Collins.

Lanser, Susan Sniader 1981. The narrative act: Point of view in prose fiction. Princeton : Princeton University Press.

Le Roux, André 1987. Sleep vir jou 'n stoel nader. Kaapstad, Pretoria : Human en Rousseau.

Letoit, André 1985. Somer 11. Johannesburg : Perskor.

Letoit, André 1989. Suidpunt-jazz. Pretoria : HAUM-Literêr.

Marais, Johann Lodewyk 1988. 'n Kort herbetragting van Uys Krige se prosa met verwysing na The dream" as sleutelteks. Literator, 9(3):19-28, Nov.

Meyer, Ilona. 1988. Fokalisering as manipuleringstegniek in jeugverhale (met spesiale verwysing na drie verhale van Dolf van Niekerk). Literator, 9(2):17-28, Aug.

Opperman, D.J. 1979. Komas uit 'n bamboesstok. Kaapstad : Human en Rousseau.

Prinsloo, Koos 1982. Jonkmanskas. Kaapstad : Tafelberg.

Prinsloo, Koos. 1987. Die hemel help ons. Emmarentia : Taurus.

Van Coller, H.P. \& Van Rensburg, M.C.J. 1982. Van mond tot oor. In: Van Jaarsveld, G.J. (red.). Wat se $j y$ ? Studies oor taalhandelinge in Afrikaans. Johannesburg: McGraw-Hill Bockmaatskappy.

Van Gorp, H. et al. 1986. Lexicon van literaire temen. Leuven : Wolters-Noordhoff.

Viljoen, Lettie 1984. Kleaglied vir Koos. Emmarentia : Taurus.

\section{Universiteit van Kaapstad}

